\title{
The Status quo of Knowledge Management and Sustainability Knowledge
}

\author{
Beate Klingenberg ${ }^{1}$ and Helen N. Rothberg ${ }^{2}$ \\ ${ }^{1}$ The Italian International Institute Lorenzo de' Medici, Firenze, Italia \\ ${ }^{2}$ Marist College, Poughkeepsie, NY, USA \\ Klingenbergb1@gmail.com \\ hnrothberg@aol.com \\ DOI: 10.34190/EJKM.18.02.004
}

\begin{abstract}
The United Nations (UN) 2030 agenda for sustainable development issues an urgent call to transition to sustainable business models and life styles. Outlining seventeen concrete sustainable development goals (SDGs), organizations and individuals are encouraged to actively participate (United Nations, 2015). However, as of the 2019 report on the SDGs, progress is slow. Organizations that aspire to be economically viable as well as socially and environmentally responsible global citizens, need to understand what sustainability means and how to institutionalize its principles. This paper posits that some of the underlying reasons for slow progress are lack of full understanding of the required knowledge and its systemic nature, as well as potentially insufficient knowledge management processes. It proposes that sustainability knowledge learning should include three "DCA" steps: 1) What to know: identify which knowledge is needed (DEFINE); 2) How to learn : develop strategies to identify sources and learning strategies for the requisite sustainability knowledge (COLLECT); 3) How to use sustainability knowledge: develop knowledge management practices that enable absorption and institutionalization $(A C T)$. Comparing the DCA model to other sustainability knowledge management models reveals that internal processes are emphasized (ACT). Fewer models consider the second step, COLLECT. The necessity to identify knowledge needs, DEFINE is almost entirely absent. Given the complex nature of sustainability knowledge, it appears that currently, knowledge management practices may be inadequately designed to support organizations in their transformational change towards sustainability and in the development of required stakeholder partnerships. Said systemic nature is also ill reflected in knowledge management research for sustainability. Further limiting is a lack of a clear definition of sustainability knowledge. This paper is a call for research to establish a clear view of what sustainability knowledge is, and based on that, a more detailed development of effective knowledge management strategies.
\end{abstract}

Keywords: sustainable development goals (SDG), sustainability knowledge, sustainable development knowledge, knowledge management process, systems thinking, learning process

\section{Introduction}

Time Magazine's 2019 choice for Person of the Year was the sixteen-year-old Greta Thunberg. This signals that concern about human impact on the earth, in this case climate change, is resonating with the developed world. Promoting the concept of sustainable development encourages organizations and individuals to move towards more sustainable business models and lifestyles.

The United Nations (UN) 2030 agenda for sustainable development outlines seventeen concrete Sustainable Development Goals (SDGs) (see Table 1) (United Nations, 2015). This adds to an "emerging sustainability megatrend" (Lubin \& Esty, 2010), requiring organizations to reorient their traditional view towards the triple bottom line (Elkington, 1994), the three P's of sustainability: profit, planet, people (Soyka, 2012). The UN 2030 agenda expands the three P's to people, planet, prosperity, peace and partnership (United Nations, 2015). Responsible economically viable citizenship calls for an integrated global framework of partnerships, in supply chains and production of goods and services, to promote "a spirit of strengthened global solidarity" (United Nations, 2015, p. 6). Seemingly a goal motivated more by altruism than traditional business goals, organizations are realizing that sustainability offers strategic opportunities for innovation and growth (Laperche and Uzunidis, 2012). New strategic models are being developed that link sustainability strategies to the established generic strategies by Porter (Cavaleri and Shabana, 2018). As such, Carter and Roger (2008) define sustainability as "the strategic, transparent integration and achievement of an organization's social, environmental and economic goals in the systemic coordination of key inter-organizational business processes for improving the long-term economic performance of the individual company and its supply chains". 
Table 1: UN 2030 agenda SDGs (UN, 2015).

\begin{tabular}{|l|l|}
\hline Number & Goal \\
\hline 1 & No poverty \\
\hline 2 & Zero hunger \\
\hline 3 & Good health and well being \\
\hline 4 & Quality education \\
\hline 5 & Gender equality \\
\hline 6 & Clean water and sanitation \\
\hline 7 & Affordable and clean energy \\
\hline 8 & Decent work and economic growth \\
\hline 9 & Industry, innovation and infrastructure \\
\hline 10 & Reduce inequalities within and among countries \\
\hline 11 & Sustainable cities and communities \\
\hline 12 & Responsible production and consumption \\
\hline 13 & Climate action \\
\hline 14 & Live below water \\
\hline 15 & Live on land \\
\hline 16 & Peace, justice and strong institutions \\
\hline 17 & Partnerships for the goals \\
\hline
\end{tabular}

The first formulation of sustainable development goals from the UN (Brundtland, et al., 1987) provides the following definition: "Sustainable Development seeks to meet the needs and aspirations of the present without compromising the ability to meet those of the future" (World Commission on Environment and Development (WCED), 1987). The 1992 United Nations Conference on Sustainable Development produced the Millennium Development Goals (MDGs), focusing on reducing poverty, deadly diseases and promoting education (United Nations Development Programme (UNDP). Twenty years later, the Rio+20 conference in 2012 provided governments, non-government organizations (NGOs), businesses and individuals frameworks to pledge sustainability programmes and launched the process to define the aforementioned seventeen SDGs (UN, 2012). Their implementation is measured by the SDG indicators (United Nations, 2019). The 2019 Report of the Secretary General of the UN on progress towards the SDGs “...demonstrates, however, that progress has been slow on many Sustainable Development Goals, that the most vulnerable people and countries continue to suffer the most and that the global response thus far has not been ambitious enough." (United Nations, 2019, p. 1). While there has been worldwide response, the report also finds that current implementations "...have not gone far enough to adequately respond to the paradigm shift required by the 2030 Agenda..." (United Nations, 2019, p. 26). The report concludes that the required changes to more sustainable practices and fundamental transitions in production, consumption and disposal of goods need to be supported by science-based targets that may be beyond the capacity of many administrations. Academic sources also note that the number of firms pursuing sustainability goals are still a minority (Zaremba-Wranke, 2015). The many sociological, political and economic root causes for the reported insufficient adaption of sustainability go beyond the scope of this paper. Rather the question here addresses whether there is enough disseminated and approachable knowledge about what sustainability and the SDGs really entail. In other words, it attempts to elucidate how firms discover and assimilate the knowledge needed to transition to more sustainable enterprises.

Knowledge is recognized as a key strategic resource (Grant, 1996, Spender 1996). The knowledge-based view of the firm (KBV) prescribes that successful change to a sustainable business model requires understanding sustainability principles and institutionalizing them throughout organizational processes. De Marchi (2012) and De Marchi and Grandinetti (2013) confirm that a profound internal knowledge base is the prerequisite to address sustainability. Knowledge management (KM) should therefore play a central role in any sustainability program. $\mathrm{KM}$ is generally viewed as the management of creating, disseminating and measuring knowledge (Turner and Minonne, 2010). An example of this view is the organizational learning cycle proposed by Sanchez $(2001,2005)$ that enables an organization to embed knowledge into its cultural frameworks, systems and processes. In detail, the author prescribes: 1 . Maintain learning loops throughout all processes; 2 . Disseminating existing and new knowledge systematically; 3. Applying knowledge wherever possible. Robinson, et al. (2006) suggest an inextricable link between sustainable development and KM. The authors propose the so-called STEPS maturity roadmap, a five step process consisting of a) start-up (increased awareness of KM and its benefits); b) take-off (development of KM strategy); c) expansion (change management to increase visibility of KM); d) progressive stage (measure and monitor to improve KM performance) and e) sustainability stage (sustaining the KM performance). Similar step-wise change processes were also proposed to guide organizations sustainability 
transformation (Doppelt, 2003; Dunphy, Griffiths and Benn, 2003; Lueneburger and Goleman, 2010; Sloan, Klingenberg and Rider, 2013)); However, Robinson, et al. (2006) focus primarily on the KM aspect. Huang and Shi (2009) introduce the Environmental Knowledge Circulation Process (EKCP) implemented by China Steel Corporation's Taiwanese operations. It encompasses: creation, accumulation, sharing, utilization and internalization. EKCP is a data base of searchable environmental knowledge, combined with e-learning courses and organizational learning routines. In this practical application, the firm appears to have created a solid internal knowledge base (De Marchi (2012) and De Marchi \& Grandinetti (2013), addressing the environmental aspect that could support its sustainability goals in the long-term. Other frameworks for environmental and social responsibility exist in the ISO14000 and ISO26000 norms (Carayannis, et al. (2017).

Frameworks for developing sustainability KM systems, as well as factual information regarding sustainability principles are available. So, it seems that organizations have access to relevant knowledge and guidelines for incorporation and application. Surprisingly, organizations still exhibit inexperience and rudimentary knowledge regarding, for example, environmental issues (Porter and Van der Linde, 1995). Lacy, Haines and Hayward (2012) posit that the implementation of sustainability is significantly hindered by lack of middle-senior management's skills and knowledge. Haugh and Talwar (2010) even call it a "leap of faith" to assume familiarity with sustainability concepts in employees and mid-level managers. Soyka (2012) and Klingenberg and Kochanowski (2015) found that organizations often appear to not fully understand the meaning and implications of sustainability, and therefore are unable to define their knowledge needs. Furthermore, they do not seem to understand how or where to look for said knowledge (Klingenberg and Kochanowski, 2015). Despeisse, et al. (2012) reported a lack of information regarding quantification of benefits, challenges of implementation and specifically knowledge management for sustainability. In other words, organizations often recognize their need for sustainability knowledge, but not what it is they need, and who may have the required information and expertise. Robinson, et al. (2006) also pointed out that organizations often lack a methodical approach for managing sustainability knowledge, while He, et al. (2019) recognize that there is little understanding as to how KM supports the development of sustainable supply chains.

In trying to understand the perceived discrepancy between availability of sustainability knowledge and implementation frameworks, and the apparent lack in confidence for organizations to take action, a closer look at the development of the concept of KM is warranted. In one of the earliest definitions Davenport (1994) described KM as "the process of capturing, developing, sharing, and effectively using organizational knowledge". Duhon (1998) defined KM as: “... a discipline that promotes an integrated approach to identifying, capturing, evaluating, retrieving and sharing all of an enterprise's information assets." Duhon added the idea of "identifying knowledge". Similarly, Scarbrough, Swan and Preston (1999) talk about KM as "any process of creating, acquiring, capturing, sharing and using knowledge, wherever it resides, to enhance learning and performance in organisation". In their seminal review on KM and Knowledge Management Systems (KMS), Alavi and Leidner (2001) describe KM's objective as supporting "creation, transfer and application of knowledge in organizations". However, the authors also present a different perspective as to what knowledge is. Following Schubert, Lincke and Schmid (1998), knowledge can be viewed as a) a state of mind; b) an object; c) a process; d) a condition of having access to information or e) a capability. While access to information may not be equal to identifying knowledge needs, this view stresses the importance of knowing where to find it. Turner and Minnone (2010) describe the first step in knowledge management as creating knowledge or learning processes. Sanchez (2001, 2005) starts the learning cycle with maintaining learning loops. It appears therefore that the general KM literature recognizes that a first step to a functioning KM process is identification of knowledge needs. Considering KM specifically in the context of sustainability, Robinson, et al. (2006) place an increased awareness of knowledge needs as step one, immediately followed by developing implementation strategies. Awareness is the first step, the need to act is the second (Rimanoczy, 2017). Although the KM literature emphasizes defining knowledge needs as the initial step in creating a KM process, this has yet to occur for understanding sustainability.

This paper posits that learning and managing sustainability knowledge requires three distinct steps (DEFINE, COLLECT, ACT or DCA):

1. What to know: specifying knowledge needs (DEFINE): learning about sustainability concepts and outlining the knowledge needed to advance the organization towards sustainability;

2. How to learn the knowledge: specifying learning methods (COLLECT): developing strategies to (a) identify suitable sources for obtaining sustainability knowledge and skills and (b) absorb and institutionalize said knowledge as the sources may be external to the organization; 
3. How to use sustainability knowledge: learning and institutionalizing the knowledge (ACT): developing adequate and effective knowledge management practices that enable absorption and dissemination of requisite knowledge throughout the organization to change the organization's business model towards a more sustainable one.

The second and third step do not differ from other KM frameworks. The differentiator is DEFINE, a step that only few authors have focused on thus far. Huang and Shi (2009) called the first step of their EKCP process "creation", a term often used in the KM literature. Creation in this context meant the development of an environmental database. This comes close to the idea of identifying knowledge needs, however, it mostly represents the COLLECT step. In an industry as highly regulated as the steel industry, and given the nature of the production process, it is straight forward that sustainability focuses on environmental concerns, and the regulatory frameworks provide an easy entrance as to what knowledge is needed. This is not the case for all industries. For a provider of an internet-based service, for example, the meaning of sustainability is less clear, supporting the argument why the first step, DEFINE, is so instrumental, as well as adding the realization that sustainability knowledge may have industry specific traits.

Current management and KM practices may not engage in the DEFINE step well, leaving organizations struggling to find a starting point. The following section elaborates on the nature of sustainability knowledge as a further argument for the need of step one. It also analyzes current literature on KM and sustainability to elucidate how much emphasis is placed on specifying knowledge needs. The last section of this paper discusses the findings, limitations of the paper and a research outlook.

\section{The literature on sustainability knowledge and KM processes}

\subsection{The nature of sustainability knowledge}

The English term "sustainability" has various meanings: 1. "the quality of being sustainable by argument; the capacity to be upheld or defended as valid, correct, or true; 2 . The quality of being sustainable at a certain rate or level; 3. The property of being environmentally sustainable..." (Oxford English Dictionary, 2012). Generally, the term is connected to the idea of upholding something. Going back to $17^{\text {th }}$ century Britain, France and Saxony, different government treaties used it to signify the upkeep of strategic resources, particularly of wood, a key resource for economic and military purposes. Specifically, it was used in the context of sustainable forest management (Gruber, 2007). Probably from this connection to nature, sustainability as understood today morphed into the general idea of sustaining the planet, human societal structures as well as maintaining economic viability.

The different meanings of sustainability reflected in the literature, are "sustainable knowledge" (i.e. knowledge that can be upheld) and "sustainability knowledge" (i.e. the knowledge of sustainability concepts). "Sustainability knowledge" is not well established in the academic management literature. It is more often found in research on education (see for example: Zwickle, et al., 2014.; Heeren, et al., 2016; and Salas-Zapata, RiosOsorio and Cardona-Arias, 2018), referring to the dissemination of knowledge to individuals, generally students, in educational settings, or the development of programs that teach sustainability concepts (see for example: Steward, 2010; and Bardy, Rubens and Eberle, 2017). Here we are concerned with sustainability knowledge as knowledge of concepts from the perspective of organizational intelligence.

The academic literature has recognized sustainability as a multidimensional and multi-stakeholder problem (Barile, et al., 2018), which demands "...individual and cumulative social, environmental and economic implications of decisions or processes based on an understanding of the systemic nature of the world, the interconnectedness of natural and human systems." (Crofton, 2000). Early literature acknowledged the need to understand sustainability in the context of human and environmental systems (Clayton and Radcliffe, 1996). However, despite growing, the management literature has not yet employed the systemic nature of sustainability as a prevalent concept (Williams, et al., 2017). Based on a review, Williams, et al. (2017) identified five core concepts that reflect this systemic nature:

- Interconnectedness: recognizing the interconnection of environmental, social and economic problems;

- Feedbacks: recognizing non-linear characteristics of system dynamics;

- Adaptive capacity/resilience: recognizing the adaptive mechanism organizations employ to counter environmental changes; 
- Self-organization: emergence dynamics that develop from self-organizing processes;

- Emergence: recognizing that existing structures may be detrimental to future emergence.

\subsection{The systemic nature of sustainability knowledge and the DCA process}

A successful KM approach for sustainability needs to embody the systemic nature of sustainability knowledge. Considering the proposed DCA process, each step needs to address different aspects:

4. Specifying knowledge needs (DEFINE): When identifying what an organization needs to know, the interconnectedness of society, economics and the natural environment is considered. For example, an organization may focus on specifying its environmental impact, however, without considering its influence on society, it may develop sustainability programs that improve said environmental impact, but could have unintended negative consequences for its stakeholders.

5. Specifying learning methods (COLLECT): Adequate learning methods address interconnectedness as well as non-linear feedback processes. The adaptive and desorptive (ACDC) capacity of an organization moderates this step (Meinlschmidt, Foerstl and Kirchoff, 2015) and are key to identifying learning strategies.

6. Learning and institutionalizing the knowledge (ACT): Adaptive capacity and the ability of selforganization define how the organization will learn the knowledge and act upon it. This learning process commands profound change to organizational structures, mental modes and business models. Transformational change is difficult to achieve (Beer and Nohria, 2000), hence it is critical to guard for barriers that could hinder emergence. In fact, this step should be supported by welldesigned and managed change management processes (Dunphy, Griffiths and Benn, 2003; Lueneburger and Goleman, 2010; Sloan, Klingenberg and Rider, 2013), specifically considering Doppelt's (2003) "seven sustainability blunders", that include a siloed approach to sustainability, lack of clear vision as to what sustainability is, lack of information and insufficient mechanisms for learning.

Because the systemic nature of sustainability knowledge branches into the DCA process, it complicates the learning process. Systems thinking is recognized as a framework for knowledge management (e.g. RubensteinMontano, et al., 2001; Gao, Li and Nakamori., 2002; Best and Holmes, 2010). Sasaki (2016) finds that systems intelligence is an effective perspective for knowledge management in the context of the SECI model (socialization, externalization, combination and internalization). The development of systems thinking is a key concept in engineering education (Keating, et al., 2016; Kordova, Frank and Miller, 2018). However, the KM literature appears to be void of approaches on how to manage systemic knowledge, i.e. knowledge that connects across different systems.

The challenge of its systemic character is also reflected in current research. Many authors regard sustainability, and hence knowledge of sustainability, exclusively from the perspective of the natural environmental and therefore concepts come from environmental science, ecology, ecosystems and environmental protection (Fryxel and Lo, 2003), overlooking its multi-faceted nature. On the other hand, the UN has framed sustainability in the developmental context, placing economic and social factors in the foreground. Sustainable development emphasizes the fundamental change from the current neoclassical economic model to a sustainable one (Rogall, 2012; Rogall and Oebels, 2010). The literature therefore is inconsistent in its focus, often singling out just one aspect of the system of sustainability, and divided between a perspective of sustainability or sustainable development. However, a detailed discussion of the commonalities and difference between these two perspectives, is beyond the scope of this paper. The literature search performed therefore considered both the sustainability as well as sustainable development perspectives, and looked for research that focused on one of the sustainability aspects only, or any combination of the three (society, economy, environment).

\section{Literature search and analysis}

\subsection{Methodology}

A literature search was performed using ProQuest Central. The search term "sustainability knowledge" resulted in 506 papers. To narrow the search to publications related also to knowledge management, the search was refined to "sustainability knowledge" and "knowledge management", resulting in 89 papers. Of these, no paper per se dealt with the development of KM processes for sustainability knowledge. A second search using the combination of "sustainability" and "knowledge management" yielded 374 publications, however, screening the papers in detail again resulted in discarding all. A narrower search was performed in journals related to knowledge management (Journal of Knowledge management, Electronic Journal of Knowledge management, 
Knowledge Management Research \& Practice), resulting in 6 papers, all of which are included in Table 2, as they specifically address KM processes and sustainability. Reviewing these papers eventually lead to the identification of the remaining papers listed in Table 2. A lack of a precise taxonomy for sustainability knowledge or inconsistent use of terminology for knowledge that regards sustainability could be a cause for the difficulty in finding adequate papers.

The papers were then searched for terms related to the three steps of the DCA process in order to identify which of the proposed steps are reflected in the described or proposed models. The results are included in Table 2, indicating which aspects of sustainability are considered, and if a paper reflects upon the systemic nature of sustainability knowledge.

\subsection{Results}

In the following, the DCA model is compared with the frameworks or approaches of the literature listed in Table 2.

Table 2: Assignment of literature to three-step process

\begin{tabular}{|c|c|c|c|}
\hline Authors & Step 1: DEFINE & Step 2: COLLECT & Step 3: $A C T$ \\
\hline $\begin{array}{l}\text { Robinson et al. (2006) } \\
\text { Systemic view of sustainability }\end{array}$ & & $\begin{array}{l}\text { STEPS maturity system, } \\
\text { chronological view of } \\
\text { change from least } \\
\text { advanced to most } \\
\text { advanced organization } \\
\text { with respect to } \\
\text { sustainability; describe } \\
\text { need to establish goals of } \\
\text { KM }\end{array}$ & $\begin{array}{l}\text { Mature organizations } \\
\text { have KM routines } \\
\text { diffused throughout } \\
\text { organization }\end{array}$ \\
\hline $\begin{array}{l}\text { Huang and Shih (2009): } \\
\text { Development of EKCP, } \\
\text { Environmental aspect }\end{array}$ & $\begin{array}{l}\text { Creation of } \\
\text { database requires } \\
\text { understanding of } \\
\text { industry needs, } \\
\text { guided by } \\
\text { regulation for steel } \\
\text { industry }\end{array}$ & $\begin{array}{l}\text { Creation of environmental } \\
\text { database, knowledge } \\
\text { accumulation }\end{array}$ & $\begin{array}{l}\text { Sharing, utilization and } \\
\text { internalization }\end{array}$ \\
\hline $\begin{array}{l}\text { Mohamed, Stankosky and } \\
\text { Mohamed (2009) } \\
\text { Mohamed, Murray and } \\
\text { Mohamed (2010) } \\
\text { Systemic view of sustainability }\end{array}$ & & & $\begin{array}{l}\text { Strategic role of } \\
\text { information and } \\
\text { communication } \\
\text { technology (ICT) }\end{array}$ \\
\hline $\begin{array}{l}\text { De Marchi and Grandinetti } \\
\text { (2013) } \\
\text { Environmental aspect }\end{array}$ & & $\begin{array}{l}\text { Importance of external } \\
\text { knowledge strategies }\end{array}$ & $\begin{array}{l}\text { Internal knowledge } \\
\text { strategies less critical, } \\
\text { but also important }\end{array}$ \\
\hline $\begin{array}{l}\text { Sala, Ciuffo and Nijkamp } \\
(2015) \\
\text { Systemic view of sustainability }\end{array}$ & & & $\begin{array}{l}\text { Sustainability } \\
\text { assessment (SA): } \\
\text { systematization of } \\
\text { knowledge on } \\
\text { technical/scientific } \\
\text { sustainability } \\
\text { evaluation }\end{array}$ \\
\hline $\begin{array}{l}\text { Meilnschmidt, Foerstl and } \\
\text { Kirchoff (2016) } \\
\text { Systemic view of sustainability } \\
\text { Supply chain focus }\end{array}$ & $\begin{array}{l}\text { Exploratory } \\
\text { learning: identify } \\
\text { and recognize } \\
\text { external knowledge }\end{array}$ & $\begin{array}{l}\text { Transformative learning: } \\
\text { Assimilate and transform } \\
\text { valuable external } \\
\text { knowledge }\end{array}$ & $\begin{array}{l}\text { Exploit assimilated } \\
\text { knowledge } \\
\text { (exploitative learning) }\end{array}$ \\
\hline $\begin{array}{l}\text { lazzolino and Laise (2016) } \\
\text { lazzolino, Laise and Gabriele } \\
\text { (2017) } \\
\text { Social and economic aspect }\end{array}$ & & & $\begin{array}{l}\text { Emphasize importance } \\
\text { of knowledge } \\
\text { investments and } \\
\text { knowledge-based } \\
\text { strategies (KS) }\end{array}$ \\
\hline $\begin{array}{l}\text { Roxas and Chadee (2016) } \\
\text { Environment aspect }\end{array}$ & & $\begin{array}{l}\text { Importance of relational } \\
\text { capital }\end{array}$ & $\begin{array}{l}\text { Knowledge- } \\
\text { management } \\
\text { orientation }\end{array}$ \\
\hline $\begin{array}{l}\text { Yang, et al. (2016) } \\
\text { Systemic view of sustainability }\end{array}$ & & & $\begin{array}{l}\text { Focus on internal KM } \\
\text { model only; } \\
\text { Acknoledge difficulty to }\end{array}$ \\
\hline
\end{tabular}




\begin{tabular}{|c|c|c|c|}
\hline Authors & Step 1: DEFINE & Step 2: COLLECT & Step 3: $A C T$ \\
\hline & & & $\begin{array}{l}\text { obtain sustainability } \\
\text { knowledge }\end{array}$ \\
\hline $\begin{array}{l}\text { Carayannis et al. (2017) } \\
\text { Use term sustainable- } \\
\text { organizational-excellence }\end{array}$ & & $\begin{array}{l}\text { Learning from artifacts and } \\
\text { routines, external }\end{array}$ & $\begin{array}{l}\text { Learning from artifacts } \\
\text { and routines, internal }\end{array}$ \\
\hline $\begin{array}{l}\text { Albort-Morant, Leal-Rodríguez } \\
\text { and De Marchi (2018) } \\
\text { Environmental aspect }\end{array}$ & & $\begin{array}{l}\text { relationship learning } \\
\text { (external knowledge-based } \\
\text { drivers) }\end{array}$ & $\begin{array}{l}\text { absorptive capacity } \\
\text { (internal knowledge- } \\
\text { based drivers }\end{array}$ \\
\hline $\begin{array}{l}\text { He, et al. (2019) } \\
\text { Systemic view of sustainability } \\
\text { Identifies KM as key enabler for } \\
\text { sustainable supply chain } \\
\text { management (SSCM), do not } \\
\text { develop their own KM model }\end{array}$ & $\begin{array}{l}\text { Considers } \\
\text { knowledge } \\
\text { identification }\end{array}$ & $\begin{array}{l}\text { Considers knowledge } \\
\text { creation }\end{array}$ & $\begin{array}{l}\text { Considers knowledge } \\
\text { discussion and } \\
\text { integration }\end{array}$ \\
\hline $\begin{array}{l}\text { López-Torres et al. } 2019 \\
\text { Environmental aspect } \\
\text { Identifies KM as key enabler for } \\
\text { sustainable operations, do not } \\
\text { develop their own KM model }\end{array}$ & & $\begin{array}{l}\text { Considers capturing } \\
\text { knowledge }\end{array}$ & $\begin{array}{l}\text { Considers } \\
\text { disseminating } \\
\text { knowledge }\end{array}$ \\
\hline
\end{tabular}

\subsubsection{Models/frameworks that address all three steps of the DCA model}

There appears to be little evidence for KM approaches that consider all three steps of the DCA model. As postulated, it is the DEFINE step that is generally missing. Huang and Shi (2009) mention the identification of knowledge (creation of knowledge) in the context of an industry with highly regulated environmental procedures, which facilitates such knowledge identification.

Meilnschmidt, Foerstl and Kirchoff's (2016) model of absorptive and desorptive capacities (ACDC) encompasses internal capacities as well as external, exploratory learning. The authors find that the ACDC mechanisms can lead to an ambidextrous ability to exploit existing and explore new knowledge. The ACDC model aligns with steps two and three of DCA. Explorative learning could represent a component of step one.

He, et al. (2019) mention aspects of a KM system that cover identification, capture and dissemination of knowledge. However, they do not elaborate on the KM system, as the focus of their research is on testing the impact of KM on the triple bottom line perspective in supply chains.

\subsubsection{Models/frameworks that address step two and three of the DCA model}

The work of Robinson, et al. (2006) is not an easy fit to the proposed DCA model, as the authors focus on the step-wise change process towards sustainability, not specifically a KM framework. However, the need to define sustainability goals (COLLECT in the sense of definition of learning strategies) and strong internal KM capabilities (ACT) is emphasized.

De Marchi and Grandinetti (2013) analyse knowledge strategies for environmental innovation (EI) of Italian manufacturing firms. Firms that the authors call "green innovators" have distinct external knowledge strategies (aligning to the COLLECT step), enabled by inter-organizational relationships throughout their supply chain, as well as strong internal knowledge strategies (investment into Research \& Development and employee training, aligning to the ACT step).

A study of environmental sustainability in small and medium enterprises (SMEs) in Philippine manufacturing sectors (Roxas and Chadee 2016) underscores the importance of knowledge-based resources, the need for a robust knowledge management approach (aligning to the ACT step) and the development of relational capital (aligning to the COLLECT step).

Carayannis, et al. (2017) explain learning as: learning itself, learning to learn, and learning to learn how to learn. The authors propose a model of organizational routines and artifacts, that mutually create each other, and are of external and internal character, aligning to COLLECT and ACT. 
Albort-Morant, Leal-Rodríguez and De Marchi (2018) investigate green innovation performance (GIP) in Spanish automotive component manufacturers, and find that absorptive capacity (ACT) has a significant impact on GIP, while relationship learning (COLLECT) is a moderator between the former and GIP.

López-Torres, et al. (2019) include aspects that reflect both COLLECT and ACT in their description of KM systems tasks. However, the focus of their paper is not to develop an actual framework, but instead to test the impact of KM on sustainability in operations.

\subsubsection{Models/frameworks that address step three of the DCA model}

Step three, ACT, is the prevalent task of KM systems in all of the papers.

Mohamed, Stankosky and Mohamed (2009), as well as Mohamed, Murray and Mohamed (2010) emphasize the importance of information and communication technology (ICT) for the successful mobilization of sustainable development knowledge. The authors prescribe a knowledge-oriented ITC infrastructure to enable knowledgesharing and to support decision quality. Clearly, ITC is supportive for the ACT step.

Sala, Ciuffo, and Nijkamp (2015) develop a framework for sustainability assessment (SA), which is not per se a knowledge management method, but rather a decision-making tool, e.g. for policy makers, institutions and productions modes, in order to arrive at methodological choices to reach sustainability targets. It can be related to the ACT step, as it refers to the management of sustainability knowledge, which informs the underlying sustainability values and principles.

Yang, et al. (2106) develop a KM model to promote sustainability in an Australian transport infrastructure. Inhouse KM methods are emphasized (ACT). The authors clearly identify the need for a "knowledgeable practitioner" and identify the lack of understanding of sustainability concepts as a key barrier to pursue sustainability knowledge, noting that this knowledge is challenging to acquire. However, the authors do not elaborate on how to overcome said challenge, or indeed where and how one might find a "knowledgeable practitioner". In other words, there is recognition of the need to DEFINE, but the concept is not further developed.

lazzolino and Laise (2016), and lazzolino, Laise, and Gabriele (2017) develop a value-added perspective of sustainability knowledge in a socio-economic context. An explicit KM framework is not presented, rather a valuation system. However, the importance of internal KM capabilities is emphasized.

\section{Conclusions, Implications, Limitations and future research}

Regardless of an increasing urgency to turn current business models into more sustainable ones, progress is slow (United Nations, 2019). Despite the importance placed on knowledge and effective KM as a key strategic differentiator in the KBV of the firm (Grant, 1996, Spender 1996), progress has been slow. Here we propose that the lack of understanding of the nature of sustainability knowledge and of concepts for effective knowledge management for sustainability may be why. The literature on sustainability knowledge is sparse, a surprising finding given the overall increase of studies in the field of sustainability and that the proposed "emerging sustainability megatrend" (Lubin and Esty, 2010) is now a decade old. Several complicating factors may explain this discrepancy:

1. An ambiguous use of the term "sustainability" in the English language;

2. Separate perspectives of sustainability and sustainable development;

3. A lack of a concise taxonomy as to what "sustainability knowledge" is;

4. Potentially different knowledge needs for different industries;

5. The systemic nature of sustainability knowledge.

Saviano et al. (2019) argue that knowledge regarding sustainability is still fragmented into disciplines. Research tends to focus on just one of the three aspects, using varying terms such as environmental knowledge, knowledge for environmental innovation, or sustainable development knowledge, often resulting in an emphasis on only the environmental aspect of sustainability. These studies are important. However, sustainability knowledge should reflect all aspects. 
Additionally, systemic knowledge is not easy to comprehend. Connectedness and non-linear feedback loops (Williams, et al., 2017) are not well incorporated into today's linear business models, and the recognized need for a science-based approach (United Nations, 2019) may just be too overwhelming.

Recognizing this complexity, the UN calls for partnerships and integrated approaches (United Nations, 2015), emphasizing the increasing importance of interfacing roles among stakeholders. A proposed "triple helix" model (Saviano, et al., 2019) considers policy makers as the interface between the environment and the economy, scientists as the interface between society and the environment, and industry as the interface between society and the economy. These authors call for strengthening the collaboration of these entities to foster knowledge co-creation. Other researchers similarly propose the development of stronger partnerships between education, indigenous knowledge of communities and their governments (see for example Bardy, Rubens, and Eberle, 2017, Ortiz-Fournier, et al., 2010; and Ali and Avdic, 2015).

Clark, et al. (2016) point out the importance of co-production in social-environmental systems (SES) and emphasize the need for stakeholder collaboration, social learning, knowledge governance and researcher training.

From a KM perspective, these complicating factors, as well as the need for collaboration and co-creation of knowledge makes it difficult to develop a complete picture of its role in the context of sustainability. Are current KM models up for the task?

As a starting point, this paper posits that the prerequisite for gaining sustainability knowledge is first and foremost, identifying knowledge needs (i.e. specifying WHAT one needs to know). While this is a well-recognized step in KM, it is overlooked in the context of sustainability knowledge. A three-step process of DEFINE (specify knowledge needs), COLLECT (specify knowledge strategies and sources), ACT (learn and institutionalize), DCA, is a proposed framework that is believed to be more suitable for the management of sustainability knowledge. Step three, ACT, is fully supported: the literature unanimously emphasizes internal KM strategies and practices such as sharing (see for example Huang and Shi, 2009; Yang, et al. 2016), internal learning cycles (Robinson, et al., 2006; Meilnschmidt, Foerstl and Kirchoff, 2016; Yang, et al., 2016; Carayannis, et al., 2017); absorptive capacity (Meilnschmidt, Foerstl and Kirchoff, 2016; Albort-Morant, Leal-Rodríguez and De Marchi, 2018) or ITC as a KM tool (Mohamed, Stankosky and Mohamed, 2009; Mohamed, Murray and Mohamed, 2010).

Step two, COLLECT, finds less support: fewer authors emphasize external KM strategies that would support the need to explore and acquire external knowledge (De Marchi and Grandinetti, 2013; Meilnschmidt, Foerstl and Kirchoff, 2016); create relational capital (Roxas and Chadee, 2016; Albort-Morant, Leal-Rodríguez and De Marchi, 2018) or employ learning of external routines and artifacts (Carayannis et al, 2017).

Step three, DEFINE, is rarely found in the literature. Huang and Shi (2009) recognize the need to create a knowledge repository, but do not ask the question what is needed, as it is prescribed by the industry they study. Meilnschmidt, Foerstl and Kirchoff (2016) propose exploratory learning to search "what is out there" as an important component of sustainability knowledge learning. He, et al. (2019) mention knowledge identification; however, their research does not focus on the actual development of a KM framework.

It appears that few authors recognize the importance of identifying knowledge needs, implying that current KM practices may not be sufficient to support organizations in their transformational process towards sustainability, or that a systematic KM approach is not widely applied in the context of sustainability. As surprising as this postulation is, it may have its root in the assumption of KM as a profit and performance supporting tool (Hibbard, 1997, O'Dell, Jackson Greyson Jr., and Essaides, 1998), which allows an organization to create value from its intangible assets (Sveiby, 1997). There is ample evidence of the successful application of KM processes in the for-profit context (see for example Prusak, 2001; Baskerville and Dulipovici, 2006 and Ragsdell, 2013). Sustainability on the other hand may still carry the myth of being an altruistic or environmentalist driven pasttime with little connection to profit driven business models (Lemonick, 2009) - incorrectly, as economic prosperity is one of its key goals (UN, 2015). In other words, the application of profit driven business tools may not be considered for activity that appears on the surface as not profit driven. As a related case in point, Rathi, Given and Forcier (2014) found that KM processes are much less prevalent in non-profit organizations (NPOs). 
One of the possible perspectives of knowledge is a condition of having access to information (Alavi and Leidner 2001), implying that KM's focus should be on organized access to content and its easy retrieval. An allencompassing "sustainability database" is difficult to imagine, due to the vastness of information it should contain. However, a long-term and ambitious goal is for integrating various global stakeholder partnerships into an interdisciplinary, intercultural and inter-industrial knowledge system.

To conclude, the modest, but important contribution of this paper is the realization that we still need to learn how to learn sustainability knowledge, and that the current available KM frameworks may be insufficient. As Doppelt (2003) pointed out sixteen years ago - insufficient mechanisms of learning are a significant hindrance to reaching sustainability.

Given the inconsistent vocabulary used in the literature for "sustainability knowledge", the authors concede limitations to the performed literature search, as research using different terminology may be missed. Due to the systemic nature of sustainability, searching only the management literature is limiting. Other disciplines such as natural sciences, social studies, political sciences and economics may also have contributions. Specifically, the engineering literature should be further explored for insights into the identification, creation, compilation and dissemination - in short, management - of systemic knowledge.

The authors would therefore close with a call for more research, addressing the following intentions: a) How to improve the definition of what sustainability knowledge entails; b) How to improve the presentation of the systemic nature of sustainability knowledge in KM and lastly, c) how to improve KM processes to include where everything starts: identifying knowledge needs.

\section{References}

Albort-Morant, G., Leal-Rodríguez, A.L. and De Marchi, V., 2018. Absorptive and relationship learning mechanisms as complementary drivers of Green Innovation Performance. Journal of Knowledge Management, 22(2), pp. 432-52.

Alavi, M. and Leidner, D.E., 2001. Review: Knowledge Management and Knowledge Management systems: conceptual foundations and research issues. MIS Quarterly, 25(1), pp. 107-36.

Ali, L. and Avdic, A., 2015. A Knowledge Management framework for sustainable rural development: the case of GilgitBaltistan, Pakistan. Electronic Journal of Knowledge Management, 13(2), pp. 103-16.

Bardy, R., Rubens, A. and Eberle, P., 2017. Building intellectual capital for sustainable development: combining local wisdom and advanced knowledge. Electronic Journal of Knowledge Management, 15(3), pp. 159-69.

Barile, S., Orecchini, F., Saviano, M. and Farioli F., 2018. People, technology, and governance for sustainability: the contribution of systems and cyber-systems thinking". Sustainable Science, (13), pp. 1197-1208.

Baskerville R. and Dulipovici A. (2006). The theoretical foundations of knowledge management. Knowledge Management Research \& Practice. 4(1), pp. 83-105.

Beer, M. and Nohira, N., 2000. Cracking the code of change. Harvard Business Review, May-June, pp. 133-41.

Best, A. and Holmes, B., (2010). Systems Thinking, knowledge and action: towards better models and methods". Evidence \& Policy: A Journal of Research, Debate and Practice, 6(2), pp. 145-59. Brundtland, G.H., Khalid, M., Agnelli, S., Al-Athel, S. and Chidzero, B., 1987. Our common future. New York.

Carayannis, E.G., Grigoroudis, E., Manlio Del, G., Della Peruta, M.R. and Sindakis, S., 2017. An exploration of contemporary organizational artifacts and routines in a sustainable excellence context", Journal of Knowledge Management, 21(1), pp. 25-56.

Carter, C.R. and Rogers, D.S., 2008. A framework of sustainable supply chain management: moving toward new theory. International Journal of Physical Distribution and Logistics Management, 38(5), pp. 360-87.

Cavaleri, S. and Shabana, K., 2018. Rethinking sustainability strategies. Journal of Strategy and Management, 11(1), pp. 217.

Clark, W.C., van Kerkhoff, L., Lebel, L. and Gallopin G.C., 2016. Crafting usable knowledge for sustainability development. Colloquium perspective. In: Proceedings of the National Academy of Sciences of the United States of America. Available at <https://www.pnas.org/content/pnas/early/2016/04/14/1601266113.full.pdf> [Accessed 12 December 2019].

Clayton, A. and Radcliffe, N.J., 1996. Sustainability: a Systems Approach. London: Earthscan,.

Crofton, F., 2000. Educating for sustainability: opportunities in undergraduate engineering, Journal of Cleaner Production, 8(5), pp. 397-405.

Davenport, T.H., 1994. Saving IT's soul: human centered information management. Harvard Business Review, 72, p. 119-31.

Duhon, B., 1998. It is all in our heads. Inform, 12, pp. 8-13.

De Marchi, V., 2012. Environmental Innovation and R\&D cooperation: empirical evidence from Spanish manufacturing firms. Research Policy,41(3), pp. 614-23.

De Marchi, V. and Grandinetti, R., 2013. Knowledge strategies for environmental innovations: the case of Italian manufacturing firms. Journal of Knowledge Management, 17(4), pp. 569-82. 
Despeisse, M., Mbaye, F., Ball, P.D. and Levers, A., 2012. The emergence of sustainable manufacturing practices. Production Planning \& Control, 23(5), pp. 354-76.

Doppelt, B., 2003. Leading Change Towards Sustainability: a Change-Management Guide for Business, Government and Civil Society, Sheffield: Greenleaf Publishing,

Dunphy, D., Griffiths, A. and Benn S., 2003. Organizational change for Corporate Sustainability, New York: Routledge.

Elkington, J., 1994. Cannibals with Forks. Gabriola Island: New Society Publishers.

Fryxel, G. and Lo, C.W., 2003. The influence of Environmental knowledge and values on managerial behaviours on behalf of the environment: An empirical examination of managers in China". Journal of Business Ethics, 46(1), pp. 45-69.

Gao, F., Li, M. and Nakamori,Y, 2002. Systems thinking on knowledge and its management: systems methodology for knowledge management. Journal of Knowledge Management, 6(1), pp.7-17.

Grant, R., 1996. Towards a knowledge-based theory of the firm. Strategic Management Journal, 17, pp. 109-23.

Gruber, U., 2007. Deep roots - A conceptual history of "sustainable development" (Nachhaltigkeit), Wissenschaftszentrum Berlin für Sozialforschung (WZB), Best.-Nr. P 2007-02, Berlin, Germany.

Haugh, H.M. and Talwar, A., 2010. How do corporations embed sustainability across the organization? Academy of Management Learning and Education, 9(3), pp. 384-96.

Heeren, A.J., Singh, A.J., Zwickle, A., Koontz, T.M. and Slagle, K.M., 2016. Is Sustainability Knowledge half the battle? An examination of Sustainability Knowledge, attitudes, norms, and efficacy to understand sustainable behaviours. International Journal of Sustainability in Higher Education, 17 (5), pp. 613-32.

He, Q., Gallear, D., Ghobadian, A. and Ramanathan R., 2019. Managing knowledge in supply chains: a catalyst to triple bottom line sustainability, Production Planning \& Control. 30, (5-4), p. 448-63.

Hibbard, J. (1997). Knowing what we know. InformationWeek, October.

Huang, P.-S. and Shih, L.-H., 2009. Effective Environmental Management through Environmental Knowledge Management. International Journal of Environmental Science and Technology, 6(1), pp. 35-50.

Iazzolino, G. and Laise, D., 2016. Value creation and sustainability in knowledge-based strategies. Journal of Intellectual Capital, 17(3), pp. 457-70.

Iazzolino, G., Laise, D. and Gabriele, R., 2017. Knowledge-based strategies and sustainability: a framework and case study approach. Measuring Business Excellence, 21(2), pp. 152-74.

Keating, C., Calida, B., Jaradat, R. and Katina, P., 2016. Engineering Management Handbook, $2^{\text {nd }}$ ed., pp. 281-316. Huntsville: American Society for Engineering.

Klingenberg, B. and Kochanowski, S., 2015. Hiring for the Green Economy - Employer perspectives on sustainability in the business curriculum. Journal of Management Development, 34, (8), pp. 997-1003.

Kordova, S.K., Frank, M. and Miller, A.N., 2018. Systems thinking education - seeing the forest through the trees. Systems, [online] 6(29). Available at <www.mpdi.com7journal/systems $>$ [Accessed 19 December, 2019].

Lemonick, M.D., 2009. Top 10 myths about sustainability. Scientific American Earth 3.0, 19(1), pp. 40-45.

Meilnschmid, J., Foerstl, K. and Kirchoff, J.F., 2016. The role of absorptive and desorptive capacity (ACDC) in sustainable supply management - a longitudinal analysis. International Journal of Physical Distribution \& Logistics Management, 46(2), pp.177-211.

Mohamed, M., Stankosky, M. and Mohamed, M., 2009. An empirical assessment of Knowledge Management criticality for Sustainable Development. Journal of Knowledge Management, 13(5), pp. 271-86.

Mohamed, M., Murray, A. and Mohamed, M., (2010). The role of Information and Communication Technology (ITC) in mobilization of sustainable development knowledge: a quantitative evaluation. Journal of Knowledge Management, 14(5), pp. 744-58.

Lacy, P., Haines, A. and Hayward, R., 2012. Developing strategies and leaders to succeed in a new era of sustainability. Journal of Management Development, 31(4), pp. 346-57.

Laperche, B. and Uzunidis, D, 2012. Eco-innovation, knowledge capital and the evolution of the firm. The IUP Journal of Knowledge Management, 10, (3), pp. 14-34.

López-Torres, G.C., Garza-Reyes, J.A., Maldonado-Guzmán, G., Kumar, V., Rocha-Lona, L. and Cherrafi, A., 2019. Knowledge Management for sustainability in operations. Production Planning \& Control, 30(10-12), pp. 813-26.

Lubin, D.A. and Esty, D., 2010. The Sustainability Imperative. Harvard Business Review, 88(5).

Lueneburger, C. and Goleman, D., 2010. The change leadership sustainability demands. MIT Sloan Management Review, Summer, pp. 49-55.

O’Dell, C.S., Essaides, N. (contributor), Jackson Grayson Jr., C., 1998. If only we knew what we know: the transfer of internal knowledge and best practice. New York: Free Press.

Ortiz-Fournier, L.V., Márquez, E., Flores F. R., Rivera-Vásquez, J. and Colon, P.A., 2010. Integrating educational institutions to produce intellectual capital for sustainability in Caguas, Puerto Rico. Knowledge Management Research \& Practice, 8(3), pp. 203-15.

Oxford English Dictionary, 2012. Oxford English Dictionary online. [online] Oxford: Oxford University Press (UK). Available at: <oed.com> [Accessed 13 December 2019].

Porter, M.E. and Van der Linde, C., 1995. Toward a new conception of the environment-competitiveness relationship. The Journal of Economic Perspectives, 9,(4), pp. 97-118.

Prusak, L., 2001. Where did knowledge management come from? IBM Systems Journal, 40(2), 1002-7. 
Ragsdell, G., 2013. Voluntary sector organizations: untapped sources of lessons for knowledge management. Proceedings of the International Conference on Intellectual Capital, Knowledge Management and Organizational Learning. (Kidmore End: Academic Conferences International Limited. October.

Rathi, D., Given, L.M. and Forcier, E., 2014. Knowledge needs in the non-profit sector: an evidence-based model of organizational practices. Journal of Knowledge Management, 20(1), pp. 23-48.

Rimanoczy, I., 2017. Big Bang Being - Developing the Sustainability Mindset. Oxon: Routledge.

Robinson, H.S., Anumba, C.J., Carrillo, P.M. and Al-Ghassani, A.M., 2006. STEPS: a Knowledge Management maturity roadmap for Corporate Sustainability. Business Process Management Journal, 12(6), pp. 793-808.

Rogall, H., 2012. Nachhaltige Ökonomie. 2nd Edition. Marburg: Metropolis.

Rogall, H. and Oebels, K., 2010. Von der traditionellen zur nachhaltigen Ökonomie. Working paper of the Institute of Management Berlin at the Berlin School of Economics and Law, Paper No. 53.

Roxas, B. and Chadee, D. 2016. Knowledge Management view of environmental sustainability in manufacturing SMEs in the Philippines. Knowledge Management Research \& Practice, 14, pp. 514-24.

Rubenstein-Montano, B., Liebowitz, J., Buchwalter, J., McCaw, D., Newman, B. and Rebeck, K., 2001. A Systems Thinking framework for Knowledge Management. Decision Support Systems, 31, (1), pp. 5-16.

Sala, S., Ciuffo, B. and Nijkamp, P., 2015. A systemic framework for Sustainability assessment. Ecological Economics, 119, pp. 314-25.

Salas-Zapata, W.A., Rios-Osorio and L. A., Cardona-Arias, J.A., 2018. Knowledge, attitudes and practices of sustainability: systematic review 1990-2016. Journal of Teacher Education for Sustainability. 20(1), pp. 46-63.

Sanchez, R., 2001. Knowledge Management and Organizational Competence. Oxford: Oxford University Press.

Sanchez, R., 2005. Knowledge Management and Organizational Learning: fundamental concepts for theory and practice. Working Paper Series NO. 2005/3, Institute of Economic Research, Lund University.

Sasaki, Y., 2016. A note on systems intelligence in knowledge management. The Learning Organization, 24(4), pp. 236-44.

Saviano, M., Barile, S., Farioli, F. and Orecchnini, F., 2019. Strengthening the science-policy-industry interface for progressing towards sustainability: a systems thinking view. Sustainability Science, 14(6), pp. 1549-64.

Scarbrough, H., Swan, J., and Preston, J. 1999. Issues in people management: knowledge management: a literature review. Institute of Personnel and Development. Wiltshire: The Cromwell Press.

Schubert, P., Lincke, D. and Schmid, B., 1998. A global knowledge medium as a virtual community: the NetAcademy Concept. In: Proceedings of the Fourth Americas Conference on Information Systems, E. Hoadley and I. Brenbasat (eds.), Baltimore, MD, August, pp. 618-20.

Soyka, P.A., 2012. Creating a sustainable organization - Approaches for enhancing corporate value through sustainability. Upper Saddle River: Pearson Education.

Sloan, K., Klingenberg, B. and Rider, C., 2013. Towards sustainability: examining the drivers and change process within SMEs. Journal of Management and Sustainability, 3(2), pp. 19-30.

Spender, J.C., 1996. Competitive advantage from tacit knowledge? Unpacking the concept and its strategic implications. In: B. Moingeon and A. Edmondson, eds. Organizational learning and competitive advantage, London: Sage Publications.

Steward, M., 2010. Transforming Higher Education: a practical plan for integrating sustainability education into the student experience. Journal of Sustainability Education, 1, pp. 195-203.

Sveiby, K.-E., 1997. The new organizational wealth: managing and measuring knowledge-based assets. New York: BerrettKohler.

Time Magazine, 2019. Time Magazine.[online] Available at: <https://time.com/person-of-the-year-2019-greta-thunberg/> [Accessed on 14 December 2019].

Turner, G. and Minnone, C., 2010. Measuring the effects of Knowledge Management Practices. Electronic Journal of Knowledge Management. 8(1), pp. 161-69.

United Nations, 2012. United Nations Conference on Sustainable Development, Rio+20. [online] Available at $<$ https://sustainabledevelopment.un.org/rio20> [Accessed 14 December 2019].

United Nations, 2015. Transforming our world: The 2030 agenda for sustainable development, A/RES/70/1. [online] Available at < https://sustainabledevelopment.un.org/post2015/transformingourworld/publication> [_Accessed 25 March, 2019].

United Nations (2019). Global indicator framework for the Sustainable Development Goals and targets of the 2030 Agenda for Sustainable Development, A/RES71/313, E/CN/.32018/2, E/CN.3/2019/2. [online] Available at $<$ https://unstats.un.org/sdgs/indicators/Global\%20Indicator\%20Framework\%20after\%202019\%20refinement Eng.pdf $>$ [ Accessed 14 December 2019].

United Nations Development Programme, 2019. Sustainable Development Goals - Background on the goals. [online] Available at $<$ https://www.undp.org/content/undp/en/home/sustainable-development-goals/background.html $>$ Accessed 14 Decembre 2019].

Williams, A., Kennedy, S., Philipp, F., and Whiteman, G., 2017.Systems thinking: a review of sustainability management research. Journal of Cleaner Production, 148, pp. 866-81.

World Commission on Environment and Development, 1987. Our Common Future. Report of the World Commission on Environment and Development. Annex to General Assembly document A/42/427.

Yang, J., Yuan, M., Yigitcanlar, T., Newman, P. and Schultmann, F., 2015.Management Knowledge to promote sustainability in Australian transport infrastructure projects", Sustainability, 7, pp. 8132-50. 
Zaremba-Warnke, S., 2015. Accomplishment of the economics of sustainable development as an opportunity to build a competitive advantage. Ekonomia I Prawo, Economics and Law. 14(1), pp. 81-93.

Zwickle, A., Koontz, T.M., Slagle, K.M. and Bruskotter, J.T., 2014.Assessing Sustainability Knowledge of a student population: developing a tool to measure knowledge in the environmental, economic and social domains", International Journal of Sustainability in Higher Education, 15(4), pp. 375-89. 